\title{
RETRACTED ARTICLE: Towards Post-National Membership: Local Voting Rights for Third-Country Nationals in Greece
}

\author{
Anna Triandafyllidou
}

Published online: 14 March 2014

(C) Springer Science+Business Media Dordrecht 2014

This article, published in Journal of International Migration and Integration with doi:10.1007/s12134-014-0327-7 has been retracted by the Publisher due to the fact that erroneously the wrong version of this article was published online. The publisher apologizes for any inconvenience caused.

This article, published in Journal of International Migration and Integration with doi:10.1007/s12134-0140327-7 has been retracted by the Publisher due to the fact that erroneously the wrong version of this article was published online. The publisher apologizes for any inconvenience caused.

A. Triandafyllidou $(\bowtie)$

European University Institute, Robert Schuman Centre for Advanced Studies, Florence, Italy e-mail: Anna.Triandafyllidou@eui.eu 